\title{
Pengaruh Dana Pihak Ketiga Terhadap Laba Bersih Pada PT. Bank Negara Indonesia (Persero), Tbk
}

\author{
Jamhuriah $^{1 *}$; Nurhayati ${ }^{2}$ \\ 1,2 Program Studi Manajemen, STIE, Bima, Nusa Tenggara Barat,Indonesia \\ jamhuria17.stiebima@gmail.com ${ }^{1 *}$; nurhayati.stiebima@ gmail.com ${ }^{2}$
}

Received 07 Juni 2021| Revised 15 Juni 2021 | Accepted 25 Juli 2021

*Korespondensi Penulis

\begin{abstract}
Abstrak
Dana Pihak Ketiga (DPK) merupakan sumber dana terpenting bagi kegiatan operasional suatu bank dan merupakan ukuran keberhasilan bank jika mampu membiayai operasinya dari sumber dana ini sehingga tujuan dari penelitian ini adalah untuk mengetahui sejauh mana pengaruh Dana Pihak Ketiga (DPK) terhadap Laba Bersih PT. Bank Negara Indonesia (Persero), Tbk periode tahun 2010-2019. Penelitian ini dikategorikan ke dalam jenis penelitian asosiatif kausal dengan metode kuantitatif. Populasi pada penelitian ini merupakan seluruh data perusahaan sepanjang periode tahun 1992 sampai dengan tahun 2019. Sampel pada penelitian ini Laporan Keuangan Tahunan diambil 10 tahun yaitu tahun 2010-2019 dengan teknik purposive sampling. Sumber data yaitu diperoleh dari data sekunder. Alat analisis data menggunakan regresi linear sederhana, koefisien korelasi, koefisien determinasi dan uji hipotesis (UjiT). Hasil penelitian ini membuktikan bahwa DPK (Dana Pihak Ketiga) berpengaruh positif dan signifikan terhadap laba bersih pada PT. Bank Negara Indonesia (Persero), Tbk. Hal ini mengindikasikan bahwa semakin banyak simpanan nasabah yang dihimpun PT. Bank Negara Indonesia (Persero), Tbk maka dapat meningkatkan kegiatan usaha bank sehingga memperoleh laba bersih yang optimal. Hal ini dapat dilihat pada hasil uji t yang lebih besar dari nilai t-tabel $(9,929>2,306)$ dengan tingkat signifikan yang lebih kecil dari $0,05(0,000<0,05)$ sehingga $\mathrm{H} 0$ ditolak dan Ha diterima artinya terdapat pengaruh langsung antara Dana Pihak Ketiga terhadap laba bersih pada PT. Bank Negara Indonesia (Persero), Tbk.
\end{abstract}

Kata Kunci : Dana Pihak Ketiga (DPK); Laba Bersih

\begin{abstract}
Third Party Funds (DPK) is the most important source of funds for the operational activities of a bank and is a measure of the success of the bank if it is able to finance its operations from this source of funds so that the purpose of this study is to determine the extent of the influence of Third Party Funds (TPF) on the Net Profit of PT. Bank Negara Indonesia (Persero), Tbk for the period 2010-2019. This research is categorized into causal associative research with quantitative method. The population in this study is all company data throughout the period 1992 to 2019. The sample in this study was the Annual Financial Statements taken for 10 years, namely 2010-2019 with purposive sampling technique. Source of data that is obtained from secondary data. The data analysis tool uses simple linear regression, correlation coefficient, coefficient of determination and hypothesis testing (T-Test). The results of this study prove that TPF (Third Party Funds) has a positive and significant effect on net income at PT. Bank Negara Indonesia (Persero), Tbk. This indicates that the more customer deposits collected by PT. Bank Negara Indonesia (Persero), Tbk can increase the bank's business activities so as to obtain an optimal net profit. This can be seen in the results of the t-test which is greater than the t-table value $(9.929>2.306)$ with a significant level smaller than $0.05(0.000<0.05)$ so that $\mathrm{HO}$ is rejected and $\mathrm{Ha}$ is accepted, meaning that there is a direct influence between the Fund Third Party to net profit at PT. Bank Negara Indonesia (Persero), Tbk.
\end{abstract}

Keywords: Third Party Funds (DPK); Net Profits 


\section{PENDAHULUAN}

Perbankan memiliki peranan yang penting dalam perekonomian Negara Perkembangan dan pembangunan perekonomian negara sangat bergantung pada peranan dan kinerja dari perbankan sebagai badan keuangan yang turut menggerakkan perekonomian nasional. Perbankan dapat membantu menyediakan dana untuk masyarakat dalam kegiatan bisnis usaha guna mendorong perekonomian negara melalui penyaluran kredit. Semakin luas dan besar kredit yang disalurkan oleh bank kepada masyarakat untuk kegiatan produktif, maka dapat mempercepat laju pertumbuhan ekonomi dalam suatu negara dan dalam kurun waktu yang lama (Kalopo dkk, 2012). Kegiatan penyaluran kredit merupakan kegiatan utama perbankan karena menghasilkan pendapatan terbesar bagi bank, sehingga kegiatan perkreditan sangat penting artinya bagi perbankan itu sendiri dalam meningkatkan profitabilitasnya dan juga mampu mempercepat laju pertumbuhan ekonomi negara.

Menurut Sudarmawanti (2017) suatu bank dikatakan sehat dapat diukur secara rentabilitas dimana nilainya terus mengalami peningkatan, hal ini juga berkaitan dengan faktor efisiensi dan kemampuan bank menjalankan kegiatan operasinya, sehingga dengan bila efisiensi biaya dilakukan, maka keuntungan yang diperoleh oleh suatu bank juga akan semakin besar. (Afriyeni \& Fernos, 2018). Sebagaimana diketahui bahwa bank menghimpun dana dari masyarakat dalam bentuk tabungan, deposito dan giro atau disebut juga dana pihak ketiga. Fungsi utama dari PT. Bank Negara Indonesia (Persero), Tbk adalah sebagai penghimpun dan penyalur dana masyarakat, untuk itu PT. Bank Negara Indonesia (Persero), Tbk harus mencapai laba bersih yang maksimum dengan tidak mengesampingkan kepentingan dari nasabah pada umumnya. Naik turunnya laba bersih salah satunya bisa dipengaruhi oleh jumlah dana pihak ketiga sebagai sumber dana utama pada bank, (Kasmir, 2015)

Dana pihak ketiga adalah dana-dana yang berasal dari masyarakat, baik perorangan maupun badan usaha, yang diperoleh bank dengan menggunakan berbagai instrumen produk simpanan yang dimiliki oleh bank. Semakin meningkatknya penghimpunan dana seperti simpanan nasabah, deposito dan giro, maka akan semakin mendorong bank BNI, Tbk untuk menyalurkan dananya melalui produk pembiayaan guna mendapatkan keuntungan (laba bersih). Laba bersih atau keuntungan merupakan salah satu tujuan utama Bank Negara Indonesia (Persero), Tbk dalam menjalankan aktivitasnya. Pihak manajemen selalu merencanakan besar perolehan laba bersih setiap periode, yang ditentukan melalui target yang harus dicapai. Dengan adanya target yang harus dicapai, pihak manajemen termotivasi untuk bekerja secara optimal. Hal ini penting karena pencapaian target merupakan salah satu ukuran keberhasilan PT. Bank Negara Indonesia (Persero), Tbk dalam menjalankan aktivitasnya, sekaligus ukuran kinerja pihak manajemen untuk ke depannya.

Dana pihak ketiga adalah pangsa pasar dana pihak ketiga yang dihimpun oleh masing-masing bank secara individu, (Sudiyatno dan Suroso, 2010). Dana pihak ketiga ini didapat dari akumulasi antara giro, tabungan, dan deposito. Penelitian ini menggunakan akumulasi antara giro, tabungan dan deposito sebagai indikator pada dana pihak ketiga. Perkembangan Dana Pihak Ketiga (DPK) pada PT. Bank Negara Indonesia (Persero), Tbk dalam 10 tahun terakhir dapat disajikan pada grafik sebagai berikut :

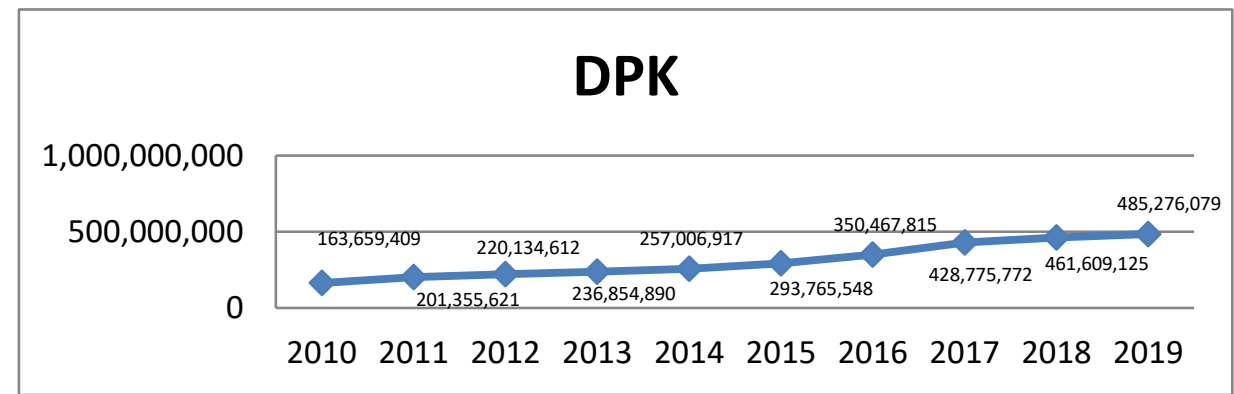

Sumber : Data Sekunder, diolah, (2021)

Grafik 1. Perkembangan Dana Pihak Ketiga Tahun 2010-2019 (Dalam Jutaan Rupiah) 
Pada aspek pendanaannya DPK (Dana Pihak Ketiga) menunjukkan pertumbuhan yang sangat baik. Dari grafik 1 dapat dilihat pada tahun 2010 Bank Negara Indonesia (Persero), Tbk dapat meraup dana pihak ketiga sebesar Rp. 163.659.409 dan terus mengalami peningkatan hingga di tahun 2019. Bank Negara Indonesia (Persero), Tbk dapat meraup dana pihak ketiga sebesar Rp. 485.276.079. Dengan komposisi Giro pada tahun 2013 sebesar Rp. 34.616.021 juta rupiah yang mengalami peningkatan hingga tahun 2019 sebesar Rp. 149.427.278 juta rupiah.. Untuk Tabungan, dan Deposito pada tahun 2013 sampai tahun 2019 mengalami kenaikan setiap tahunnya. Dapat disimpulkan bahwa pertumbuhan. Dana Pihak Ketiga dari tahun 2013 hingga tahun 2019 cenderung meningkat setiap tahunnya. Peningkatan dana pihak ketiga menunjukkan tingkat kepercayaan masyarakat yang menitipkan dananya di Bank Negara Indonesia (Persero), Tbk makin membaik. Hal tersebut didukung oleh peningkatan layanan industri jasa keuangan yang senantiasa berupaya mengoptimalkan infrantruktur dan memberikan service excelent kepada masyarakat, diantaranya pemanfaatan IT dan peningkatan jumlah kantor cabang serta pemanfaatan layanan yang prima serta kemudahan dalam meakukan transaksi.

Pada umumnya suatu perusahaan didirikan dengan tujuan untuk memperoleh laba bersih) yang maksimum. Menurut Surat Edaran Otoritas Jasa Keuangan (POJK) Nomor 39 /SEOJK.03/2017 (Otoritas Jasa Keuangan, 2017), Laba bersih adalah laba bersih tahun berjalan yang diperoleh BNI, Tbk setelah dikurangi taksiran pajak penghasilan. Menurut (Lubis, 2013), bank yang sehat akan dapat melakukan kinerja yang baik dan menghasilkan laba yang optimal. Pertumbuhan laba yang optimal mencerminkan sistem yang terdapat didalamnya berjalan dengan efektif dan efisien.

Laba bersih adalah laba bersih tahun berjalan yang diperoleh Bank Negara Indonesia (Persero), Tbk setelah dikurangi dengan taksiran pajak penghasilan. Kemampuan Bank Negara Indonesia (Persero), Tbk untuk mendapatkan laba bersih, bergantung pada kemampuan Bank Negara Indonesia (Persero), Tbk melakukan efisiensi biaya operasional terhadap pendapatan operasional, Analisis trend terhadap kemampuan memperoleh laba bersih Bank Negara Indonesia (Persero), Tbk selama tahun 2013 sampai dengan tahun 2019, di mana laba bersih tahun 2019 menjadi tahun dasar analisa dapat dijelaskan melalui tabel sebagai berikut:

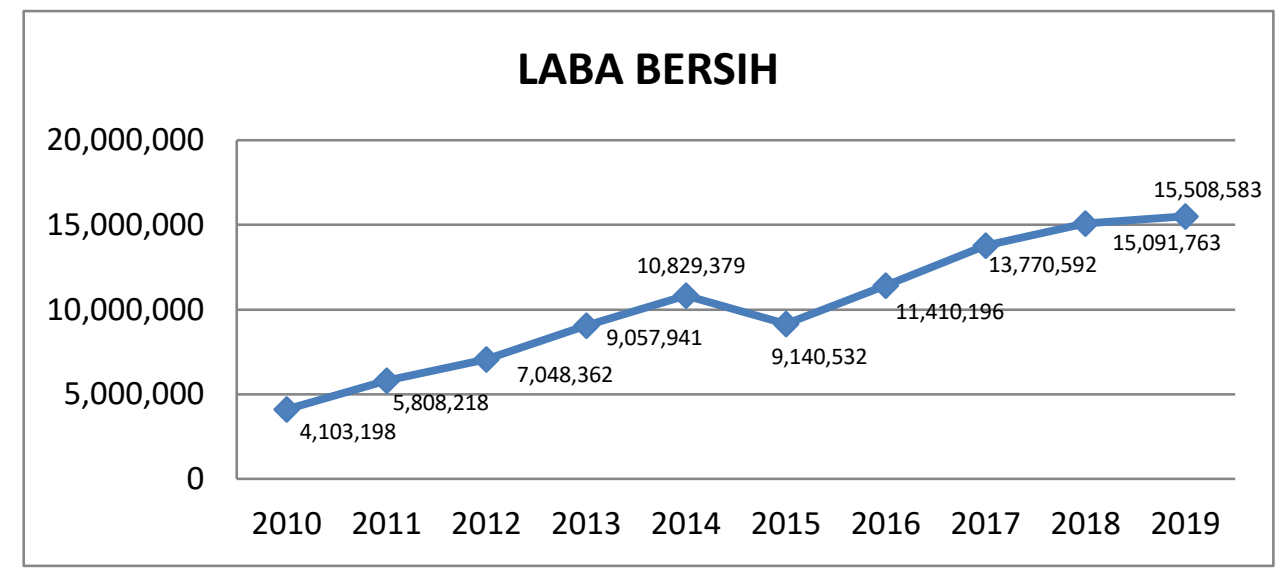

Sumber : Data Sekunder, diolah, (2021)

Grafik 2. Perkembangan Laba Bersih tahun 2010-2019

(Dalam Jutaan Rupiah)

Grafik di atas menjelaskan bahwa Laba bersih Bank Negara Indonesia (Persero), Tbk setelah dikurangi dengan pajak penghasilan, pada tahun 2010 sebesar Rp.4.103.198 (Jutaan Rupiah), dan trend perolehan laba bersih pada tahun 2011 sampai dengan tahun 2014 mengalami peningkatan. Pada tahun 2015 Laba bersih setelah dikurangi pajak penghasilan posisinya menurun menjadi sebesar Rp. 9.140.532 (Jutaan rupiah), penurunan laba bersih pada tahun 2015 disebabkan oleh adanya kenaikan biaya operasional bank. Pada tahun 2016 sampai dengan tahun 2019 Laba bersih Bank Negara Indonesia 
(Persero), Tbk kembali memperoleh trend positif dan meningkat menjadi sebesar Rp. 15.508.583 (Jutaan rupiah). dibandingkan dengan tahun 2015.

Peningkatan Laba sebelum pajak ini disebabkan karena adanya kontribusi selisih antara pendapatan non operasional setelah dikurangi biaya atau beban non operasional. Pendapatan non operasional adalah semua pendapatan yang berasal dari kegiatan yang bukan merupakan kegiatan utama Bank Negara Indonesia (Persero), Tbk, terdiri atas keuntungan penjualan aset tetap dan inventaris milik Bank Negara Indonesia (Persero), Tbk, termasuk juga barang jaminan yang diserahkan debitur kepada Bank Negara Indonesia (Persero), Tbk. Sedangkan Biaya atau beban non operasional, pemulihan penuruanan nilai dan bunga antar kantor. Sedangkan Biaya atau beban non operasional adalah biaya yang dikeluarkan atas kegiatan yang bukan merupakan kegiatan utama Bank Negara Indonesia (Persero), Tbk, terdiri atas kerugian penjualan aset, kerugian penurunan nilai wajar aset tetap, dan beban bunga antar kantor yaitu beban bunga atas dana yang berasal dari transaksi antar kantor

Kondisi Laba bersih Bank Negara Indonesia (Persero), Tbk yang terus mengalami peningkatan selama 9 tahun terakhir ini seharusnya bisa lebih optimal lagi peningkatannya, jika manajemen Bank Negara Indonesia (Persero), Tbk mampu melakukan efisiensi terhadap Kinerja Keuangan yang berhubungan dengan Dana Pihak Ketiga dan Biaya Operasional.. Semakin kurang efisien Bank Negara Indonesia (Persero), Tbk dalam pengelolaan kinerja keuangan dan biaya operasional bank dan pengelolaan Dana Pihak Ketiga maka secara perlahan akan memangkas kemampuan laba yang diperoleh sehingga laba yang dihasilkan tidak optimal.

Berdasarkan uraian yang telah dipaparkan menunjukkan bahwa terdapat kecenderungan peningkatan pada penghimpunan dana pihak ketiga yang diikuti dengan pertumbuhan positif pada laba PT. Bank Negara Indonesia (Persero), Tbk sampai tahun 2014 sedangkan pada tahun 2015, laba bersih pada tahun tersebut mengalami penurunan. Oleh karena itu penelitian ini bertujuan untuk melihat apakah kecenderungan peningkatan dana pihak ketiga berpengaruh terhadap laba bersih pada PT. Bank Negara Indonesia (Persero), Tbk . Hasil penelitian oleh Arisanti (2010) menunjukan bahwa dengan meningkatnya dana pihak ketiga, maka dana yang digunakan untuk pemberian kredit kepada masyarakat juga akan meningkat, sehingga akan meningkatkan pula pendapatanyang diperoleh yang akan berdampak terhadap peningkatan profitabilitas (laba bersih) bank tersebut. penelitian yang dilakukan oleh Luh Puspawati, Wayan Cipta , Ni Nyoman Yulianthini (2016) juga menunjukan bahwa ada pengaruh yang positif dan signifikan dari Dana Pihak Ketiga dan Jumlah Penyaluran Kredit terhadap Laba

Berdasarkan latar belakang eerta penelitian sebelumnya, maka penulis tertarik untuk melakukan penelitian serta membahas masalah tersebut dengan tema Pengaruh Dana Pihak Ketiga Terhadap Laba Bersih Pada PT. Bank Negara Indonesia (Persero), Tbk. sehingga tujuan dari penelitian ini adalah untuk mengetahui besarnya pengaruh Dana Pihak Ketiga terhadap Laba Bersih pada PT. Bank Negara Indonesia (Persero), Tbk.

\section{Dana Pihak Ketiga}

Dana pihak ketiga yaitu dana yang diperoleh melalui nasabah yang dana lebih. Bank memperoleh dana melalui nasabah yakni dengan simpanan diantaranya deposito berjangka dan atabungan. Kegiatan memperoleh dana pihak ketiga adalah operasional yang paling diharapkan dan paling terpenting karena semakin tinggi atau besarnya tingkat dana pihak ketiga berpengaruh jumlah dana yang didistribusikan pada nasabah dengan cara kredit agar memiliki pengaruhuntuk penghasilan suatu bank berdasarkan perbedaan bunga tabungan dengan bunga kredit (Wiagustini, 2018).

Kasmir (2015) menyatakan bahwa "dana pihak ketiga adalah dana yang dihimpun oleh bank dan bersumber dari masyarakat luas dalam bentuk simpanan giro, simpanan tabungan, simpanan deposito (simpanan berjangka). Sedangkan Veithzal (2013) menyatakan dana pihak ketiga adalah dana yang 
diperoleh dari masyarakat, dalam arti masyarakat sebagai individu, perusahaan, pemerintah, rumah tangga, koperasi, yayasan dan lain-lain baik dalam mata uang rupiah maupun valuta asing. Pada sebagian besar atau setiap bank, dana masyarakat ini umumnya merupakan dana terbesar yang dimiliki.

Berdasarkan beberapa definisi diatas, maka dapat dikatakan bahwa dana pihak merupakan dana yang bersumber dari masyarakat individu maupun badan usaha dalam bentuk mata uang rupiah maupun dalam mata uang asing. Dana pihak ketiga merupakan sumber dana yang terpenting bagi kegiatan operasional suatu bank yang dapat digunakan bank dalam membiayai kegiatan operasionalnya dari sumber dana ini

Masyarakat yang kelebihan dana dapat menyimpan dananya di bank dalam bentuk tabungan, deposito, giro, sertifikat deposit. Perhitungan Dana Pihak Ketiga Menurut Ismail, (2013). Adapun jenis Dana Pihak Ketiga adalah sebagai berikut :

a. Simpanan Giro merupakan simpanan yang berasal dari dana pihak ketiga yang penarikannya dapat dilakukan sewaktu-waktu dengan menggunakan sarana penarikan berupa cek, bilyet giro, dan sarana penarikan lainnya. Giro sangat bermanfaat bagi masyarakat dalam melakukan transaksi bisnisnya, karena memberikan kemudahan tersendiri. Memiliki rekening giro, sama dengan memiliki uang tunai. Karena sifat rekening giro dapat dicairkan setiap saat.

b. Simpanan Tabungan adalah simpanan yang penarikannya hanya dapat dilakukan menurut syarat tertentu yang telah disepakati, tetapi tidak dapat ditarik dengan cek, bilyet giro atau alat lainnya yang dapat dipersamakan dengan itu.

c. Simpanan Deposito merupakan jenis simpanan yang penarikannya hanya dapat dilakukan sesuai dengan jangka waktu yang telah diperjanjikan antara bank dan nasabah. Deposito dibedakan menjadi tiga jenis, yaitu: deposito berjangka, sertifikat deposito, dan deposito on call.

Menurut Muljono, (2016) mendefinisikan Dana Pihak Ketiga (DPK) adalah dana yang dihimpun dari masyarakat ini akan digunakan untuk pendanaan sektor riil melalui penyaluran kredit. Dana pihak ketiga ini dihimpun oleh bank melalui berbagai macam produk dana yang ditawarkan pada masyarakat luas, baik dalam mata uang rupiah atau mata uang asing yang terdiri dari simpanan giro, simpanan tabungan, dan simpanan deposito. Perhitungan dana pihak ketiga adalah sebagai berikut, perhitungan menurut (Ismail, 2013) dapat dirumuskan sebagai berikut :

\section{Laba Bersih}

DPK = Tabungan + Giro + Deposito

Laba bersih adalah kelebihan seluruh pendapatan atas seluruh biaya untuk suatu periode tertentu setelah dikuarangi pajak penghasilan yang disajikan dalam bentuk laporan laba rugi. Laba bersih dapat berarti berbeda-beda sehingga selalu membutuhkan klarifikasi. Laba bersih yang ketat berarti setelah semua pemotongan (sebagai lawan hanya pemotongan tertentu yang digunakan terhadap laba kotor atau marjin) (Halim, 2014).

Laba sebagai sebagai suatu excess dari business income terhadap business expenses. Bisnis memperoleh uang setelah menjual barang atau jasa mereka.Jika uang yang mereka dapat lebih dari uang yang mereka keluarkan untuk membuat/menyediakan barang/jasa, dikatakan bahwa bisnis telah membuat sebuah laba akuntansi. Menurut Kartikahudi (2012) Laba memiliki empat karakteristik sebagai berikut:

a. Laba akuntansi didasarkan pada transaksi aktual terutama dari penjualan barang/jasa.

b. Laba Akuntansi didasarkan pada postulat periodik dan mengacu pada kinerja perusahaan dalam periode tertentu.

c. Laba akuntansi didasarkan pada prinsip pendapatan yang memerlukan pemahaman khusus menenai definisi, pengukuran, dan pengakuan pendapatan.

d. Laba akuntansi memerlukan pengukuran beban dalam bentuk historical cost. 
Laba akuntansi membutuhkan penandingan antara pendapatan dan biaya yang relevan terhadap laba tersebut. Harahap (2011) menyebutkan bahwa laba memiliki beberapa karakteristik antara lain sebagai berikut:

a. Laba didasarkan pada transaksi yang benar-benar terjadi,

b. Laba didasarkan pada postulat periodisasi, artinya merupakan prestasi perusahaan pada periode tertentu,

c. Laba didasarkan pada prinsip pendapatan yang memerlukan pemahaman khusus tentang definisi, pengukuran, dan pengakuan pendapatan,

d. Laba memerlukan pengukuran tentang biaya dalam bentuk biaya historis yang dikeluarkan perusahaan untuk mendapatkan pendapatan tertentu, dan

e. Laba didasarkan pada prinsip penandingan (matching) antara pendapatan dan biaya yang relevan dan berkaitan dengan pendapatan tersebut.

Stice, Stice dan Skousen (2011), menyatakan laba sesudah pajak atau laba bersih merupakan laba setelah dikurangi dengan pajak. Laba bersih dipindahkan kedalam perkiraan laba ditahan atau Ratainer Earning. Dalam perkiraan ini akan diambil suatu jumlah tertentu untuk dibagikan sebagai deviden kepada para pemegang saham. Menurut Jumingan dalam (Andriani \& Nugraha, 2018) bahwa untuk mencapai laba yang optimal (dalam perencanaan laba maupun realisasi), manajer dapat menggunakan langkah-langkah berikut:

a. Menekan biaya operasional serendah mungkin dengan mempertahankan tingkat harga jual dan volume penjualan yang ada.

b. Menentukan tingkat harga jual sedemikian rupa sesuai dengan laba yang dikehendaki.

c. Meningkatkan volume penjualan sebesar mungkin.

Laba terdiri dari empat elemen utama yaitu pendapatan (revenue), beban (expense), keuntungan (gain), dan kerugian (loss). Defenisi dari elemen-elemen laba tersebut telah dikemukakan oleh Arfan Ikhsan (2013) sebagai berikut :

a. Pendapatan (revenue) adalah arus masuk atau peningkatan lain dari aktiva suatu entitas atau pelunasan kewajibannya (atau kombinasi dari keduanya) dari penyerahan atau produksi suatu barang, pemberian jasa atau aktivitas lain yang merupakan usaha terbesar atau usaha utama yang sedang dilakukan entitas tersebut

b. Beban (expense) adalah arus keluar atau penggunaan lain dari aktiva atau timbulnya kewajiban (atau kombinasi keduanya) dari penyerahan atau produksi suatu barang, pemberian jasa, atau pelaksanaan aktivitas lain yang merupakan usaha terbesar atau usaha utama yang sedang dilakukan entitas tersebut.

c. Keuntungan (gain) adalah peningkatan dalam ekuitas (aktiva bersih) dari transaksi sampingan atau transaksi yang terjadi sesekali dari suatu entitas dan dari semua transaksi, kejadian, dan kondisi lainnya yang mempengaruhi entitas tersebut, kecuali yang berasal dari pendapatan atau investasi pemilik.

d. Kerugian (loss) adalah penurunan dalam ekuitas (aktiva bersih) dari transaksi sampingan atau transaksi yang terjadi sesekali dari suatu entitas dan dari semua transaksi, kejadian, dan kondisi lainnya yang mempengaruhi entitas tersebut, kecuali yang berasal dari pendapatan atau investasi pemilik

Margin laba bersih merupakan rasio yang digunakan untuk mengukur besarnya persentase laba bersih atas penjualan bersih. Rasio ini dihitung dengan membagi laba bersih terhadap penjualan bersih. Laba bersih sendiri dihitung sebagai hasil pengurangan antara laba sebelum pajak penghasilan dengan beban pajak penghasilan. Yang dimaksud dengan laba sebelum pajak penghasilan disini adalah laba operasional ditambah dengan pendapatan dan keuntungan lain-lain. Semakin tinggi marjin laba bersih 
berarti semakin tinggi pula laba bersih yang dihasilkan dari penjualan bersih. Hal ini dapat disebabkan karena tingginya laba sebelum pajak penghasilan. Sebaliknya, semakin rendah margin laba bersih berarti semakin rendah pula laba bersih yang dihasilkan dari penjualan bersih. Hal ini dapat disebabkan karena rendahnya laba sebelum pajak penghasilan.

Laba bersih adalah laba operasi dikurangi beban lain lain termasuk pajak pada suatu periode tertentu. Menurut Kasmir (2011) menyatakan bahwa pengertian laba bersih (Net Profit) merupakan laba yang telah dikurangi biaya-biaya yang merupakan beban perusahaan dalam suatu periode tertentu termasuk pajak. Menurut Budi Rahardjo (2010) laba bersih dapat dihitung dengan rumus sebagai berikut :

Laba bersih $=$ Laba - Beban Pajak

Keterangan

Laba $\quad=$ Laba kotor pada perioder tertentu.

Beban pajak = Biaya pajak perusahaan pada periode tertentu

\section{Kerangka Pemikiran}

Dana yang bersumber dari masyarakat luas atau dana pihak ketiga (DPK) merupakan sumber dana terpenting bagi kegiatan operasional suatu bank dan merupakan ukuran keberhasilan bank jika mampu membiayai operasinya dari sumber dana ini (Kasmir, 2014). Laba bersih (Net Profit) merupakan laba yang telah dikurangi biaya-biaya yang merupakan beban perusahaan dalam suatu periode tertentu termasuk pajak. Menurut Kasmir, (2014) dikemukakan bahwa jika dana yang dihimpun bank mengalami kenaikkan maka laba yang diperoleh suatu Bank akan ikut mengalami kenaikan.

Penelitian yang dilakukan oleh Arisanti (2010) menunjukan bahwa dengan meningkatnya dana pihak ketiga, maka dana yang digunakan untuk pemberian kredit kepada masyarakat juga akan meningkat, sehingga akan meningkatkan pula pendapatanyang diperoleh yang akan berdampak terhadap peningkatan profitabilitas (laba bersih) bank tersebut. penelitian yang dilakukan oleh Luh Puspawati, Wayan Cipta , Ni Nyoman Yulianthini (2016) juga menunjukan bahwa ada pengaruh yang positif dan signifikan dari Dana Pihak Ketiga dan Jumlah Penyaluran Kredit terhadap Laba. Hasil berbeda dari penelitian Fauziah Durotul Masruroh, Rokhmat Subagiyo (2019) bahwa Dana pihak ketiga tidak berpengaruh signifikan terhadap laba Bank Syariah Mandiri. Berdasarkan kerangka teori di atas dapat dibuatkan paradigma penelitian sebagai berikut:

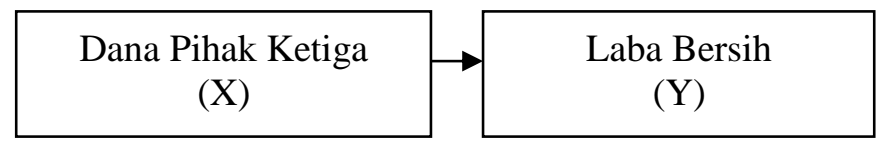

Gambar 3. Kerangka Berpikir

\section{Hipotesis Penelitian}

Hipotesis adalah suatu konklusi yang sifatnya masih sementara atau pernyataan berdasarkan pada pengetahuan tertentu yang masih lemah dan harus dibuktikan kebenarannya (Sugiyono, 2015). Dengan demikian hipotesa merupakan dugaan sementara yang nantinya akan diuji dan dibuktikan kebenarannya melalui analisa. Berdasarkan rumusan masalah dan uraian teori, penelitian, maka hipotesis yang diajukan adalah sebagai berikut :

Ho : $\beta=0, \quad$ Dana Pihak Ketiga (DPK) tidak berpengaruh signifikan terhadap laba bersih pada Bank Negara Indonesia (Persero), Tbk.

Ha $: \beta \neq 0, \quad$ Dana Pihak Ketiga (DPK) berpengaruh signifikan terhadap laba bersih pada Bank Negara Indonesia (Persero), Tbk.

\section{METODE}

\section{Jenis Penelitian}


Jenis penelitian yang digunakan dalam penelitian ini adalah penelitian asosiatif yaitu suatu jenis penelitian yang menyatakan hubungan antara dua variabel atau lebih dan hubungan sebab akibat. Dimana adanya variabel yang mempengaruhi dan variabel yang dipengaruhi, Sugiyono (2013). Jenis data yang digunakan dalam penelitian ini adalah data kuantitatif. Data kuantitaif adalah data yang berbentuk angka atau data kualitatif yang diangkakan/scoring (Sugiyono, 2017). Data yang digunakan dalam penelitian ini adalah Dana Pihak Ketiga dan Laba Bersih pada PT. Bank Negara Indonesia (Persero), Tbk. Sedangkan sumber data bersumber dari data skunder.

\section{Populasi, Sampel dan Sampling Penelitian}

Populasi adalah wilayah generalisasi yang terdiri atas objek atau subjek yang mempunyai kuantitas dan karakteristik tertentu yang ditetapkan oleh peneliti untuk dipelajari dan kemudian ditarik kesimpulannya (Sugiyono, 2017). Berdasarkan pengertian terebut, maka populasi pada penelitian ini adalah data laporan keuangan tahunan pada PT. Bank Negara Indonesia (Persero), Tbk sejak menjadi perusahaan terbuka pada tahun 1992 sampai dengan tahun 2019. Sampel adalah bagian dari populasi sehingga sampel pada penelitian ini diambil 10 tahun yaitu tahun 2010 sampai dengan tahun 2019 . Teknik sampling menggunakan purposive sampling (dengan pertimbangan tertentu karena ketersediaan data terbaru. Hal ini disebabkan karena data tersebut masih mudah untuk diperoleh dan merupakan data yang terbaru sehingga masih relevan untuk saat ini.

\section{Metode Pengumpulan Data}

Teknik pengumpulan data yang digunakan dalam penelitian ini adalah teknik dokumentasi. Dokumen merupakan cacatan peristiwa yang sudah berlalu (Sugiyono, 2017). Jadi, teknik pengumpulan data dokumentasi adalah suatu cara yang digunakan untuk memperoleh data dan informasi dalam bentuk buku, arsip, dokumen, tulisan angka dan gambar yang berupa laporan keuangan serta keterangan yang dapat mendukung penelitian. Dalam penelitian ini dokumen yang digunakan adalah sejarah perusahaan serta laporan keuangan tahunan PT. Bank Negara Indonesia (Persero), Tbk.

\section{Teknik Analisis Data}

Teknik analisis data yang digunakan dalam penelitian ini adalah dengan melakukan analisis kuantitatif yang dinyatakan dengan angka-angka yang dalam perhitungannya menggunakan metode statistic yang dibantu dengan program pengolah data statistic SPSS versi 23.0 (Ghozali, 2016). Metodemetode analisis yang digunakan mencakup uji statistik, uji analisis regresi linier sederhana, analisis Koefisien product moment, uji koefisien determinasi R2, dan uji signifikansi. Uji- t (Uji Signifikan) digunakan untuk mengetahui seberapa jauh pengaruh satu variabel independen terhadap variabel dependen". Derajat signifikansi yang digunakan adalah 0,05 dengan kriteria pengujian sebagai yaitu jika sig. $<\alpha=5 \%(0,05)$ maka Ha diterima dan $\mathrm{H} 0$ ditolak artinya terdapat pengaruh signifikan Dana Pihak Ketiga terhadap Laba Bersih dan jika sig. $>\alpha=5 \%(0,05)$ maka Ha ditolak dan H0 diterima artinya tidak terdapat pengaruh signifikan antara Dana Pihak Ketiga terhadap Laba Bersih

\section{HASIL DAN PEMBAHASAN}

\section{Regresi Linier Sederhana}

Untuk membentuk suatu persamaan regresi ganda dibutuhkan nilai konstanta dan nilai koefisien variabel Y. Hasil analisis regresi linier sederhana dengan menggunakan program SPSS 23.0 for windows adalah sebagai berikut : 
Tabel 1. Regresi Linier Sederhana

Coefficients $^{\text {a }}$

\begin{tabular}{|c|c|c|c|c|c|c|}
\hline \multirow{2}{*}{\multicolumn{2}{|c|}{ Model }} & \multicolumn{2}{|c|}{ Unstandardized Coefficients } & \multirow{2}{*}{$\begin{array}{c}\text { Standardized Coefficients } \\
\text { Beta } \\
\end{array}$} & \multirow[t]{2}{*}{$\mathrm{t}$} & \multirow[t]{2}{*}{ Sig. } \\
\hline & & $\mathrm{B}$ & Std. Error & & & \\
\hline 1 & (Constant) & .126 & 1.073 & & .117 & .910 \\
\hline & DPK & .032 & .003 & .962 & 9.929 & .000 \\
\hline
\end{tabular}

a. Dependent Variable: Laba bersih

Sumber : Data sekunder, diolah 2021

Berdasarkan hasil analisis regresi linier pada output SPSS di atas dapat diketahui bahwa nilai kostanta (a) sebesar 0,126 dan nilai koefisien regresi (b) sebesar 0,032, dan dimasukkan dalam persamaan regresi sederhana sebagai berikut: $\mathrm{Y}=0,126+0,032 \mathrm{X}$. Persamaan tersebut di atas mempunyai makna:

1. Koefisien konstanta 0,126 artinya jika Dana Pihak Ketiga yang terdiri dari giro, tabungan dan deposito sama dengan nol, maka laba bersih akan naik sebesar 0,126. Maksudnya adalah apabila besarnya giro, tabungan dan deposito sama dengan nol, maka bank akan mengalami kenaikan laba bersih sebesar 0,126.

2. Koefisien variabel $(\mathrm{b})=0,032$. Nilai koefisien regresi laba bersih yang positif ini menunjukkan bahwa setiap kenaikan Dana Pihak Ketiga $1 \%$ maka laba bersih akan mengalami peningkatan sebesar 0,032 .

\section{Analisis Koefisien Korelasi dan Koefisien Determinasi}

Uji korelasi product moment digunakan untuk mencari keeratan hubungan antara variabel Dana Pihak Ketiga terhadap laba bersih. Hasil uji koefisien korelasi product moment adalah sebagai berikut:

Tabel 2. Koefisien Korelasi

Model Summary

\begin{tabular}{lrrrr}
\hline Model & R & R Square & Adjusted R Square & Std. Error of the Estimate \\
\hline 1 & $.962^{\mathrm{a}}$ & .925 & .916 & 1.127571 \\
\hline
\end{tabular}

a. Predictors: (Constant), DPK

Sumber : Data sekunder, diolah 2021

Dalam output SPSS pada tabel Model Summary diperoleh nilai koefisien korelasi (R) sebesar 0,986 atau 98,6\% yang berarti tingkat hubungan antar variable giro $\left(\mathrm{X}_{1}\right)$, tabungan $\left(\mathrm{X}_{2}\right)$, deposito $\left(\mathrm{X}_{3}\right)$, dan laba (Y) perusahaan sub sector lembaga pembiayaan di Bursa Efek Indonesia (BEI), termasuk pada tingkat hubungan yang sangat kuat. Nilai koefisien determinasi $\left(\mathrm{R}^{2}\right)$ adalah 0.961 , maka koefesien determinasinya $=0,961 \times 100 \%=96,1 \%$ secara serentak dalam menjelaskan variasi atau perubahan variabel terikat (Y) didapati besarnya pengaruh variabel bebas 96,1\% sedangkan sisanya yaitu $100 \%$ $96,1 \%=3,9 \%$ dipengaruhi oleh variabel lain diluar variabel penelitian

Berdasarkan hasil uji koefisien korelasi product moment pada output SPSS 4.2, maka diperoleh nilai korelasi yaitu sebesar. $0.962(96,2 \%)$ atau $0,962 \times 100 \%=96,2 \%$, artinya tingkat keeratan hubungan antara variabel Dana Pihak Ketiga terhadap laba bersih PT. Bank Negara Indonesia (Persero), Tbk berada pada tingkat keeratan hubungan yang kuat

Berdasarkan uji koefisien determinasi (R square) pada tabel 4.3 dapat diketahui bahwa nilai koefisien determinasi adalah sebesar 0,925 atau sebesar 92,5\% (0,925x100\%), artinya kontribusi variabel Dana Pihak Ketiga terhadap laba bersih pada PT. Bank Negara Indonesia (Persero), Tbk adalah sebesar 92,5\%, sedangkan sisanya sebesar 7,5\% dipengaruhi oleh variabel lain seperti BOPO, CAR, NPL yang tidak dimasukkan dalam penelitian ini.. Dengan demikian kontribusi Dana Pihak Ketiga terhadap laba bersih tergolong sangat baik. 


\section{Pengujian Hipotesis (Uji-t)}

Analisa signifikasi (Uji-t) digunakan untuk mengetahui ada tidaknya pengaruh yang signifikan antara Dana Pihak Ketiga terhadap laba bersih. Adapun kriteria pengukuran signifikan atau tidanya adalah sebagai berikut :

1. Jika nilai signifikan ( $\operatorname{sig}>0,05$ ), nilai t-hitung tidak signifikan

2. Jika nilai signifikan ( $\mathrm{sig}<0,05$ ), nilai t-hitung signifikan

Hasil analisis uji hipotesis Dana Pihak Ketiga terhadap laba bersih adalah sebagai berikut:

Tabel 3. Uji T

Coefficients $^{\mathrm{a}}$

\begin{tabular}{|c|c|c|c|c|c|}
\hline \multirow[b]{2}{*}{ Model } & \multicolumn{2}{|c|}{ Unstandardized Coefficients } & Standardized Coefficients & \multirow[b]{2}{*}{$\mathrm{t}$} & \multirow[b]{2}{*}{ Sig. } \\
\hline & B & Std. Error & Beta & & \\
\hline 1 (Constant) & .126 & 1.073 & & .117 & .910 \\
\hline DPK & .032 & .003 & .962 & 9.929 & .000 \\
\hline
\end{tabular}

a. Dependent Variable: Laba bersih

Sumber : Data sekunder, diolah 2021

Hasil uji signifikan pada tabel output SPS 4.4 diperoleh nilai t-hitung adalah sebesar 9,929 dengan tingkat signifikan sebesar 0,000 . Nilai t-hitung tersebut kemudian dibandingkan dengan nilai t-tabel pada tingkat kepercayaan 95\% $(\mathrm{p}=0,05) \mathrm{dk}=\mathrm{n}=10(10-2=8)$ uji dua pihak, maka diperoleh nilai $\mathrm{t}-$ tabel $=2,306$. Dengan membandingkan nilai t-hitung dan nilai t-tabel di atas maka dapat diketahui bahwa nilai t-hitung lebih besar dari pada nilai t-tabel $(9,929>2,306)$ dengan tingkat signifikan yang lebih kecil dari $0,05(0,000<0,05)$ sehingga $\mathrm{H} 0$ ditolak dan $\mathrm{H} 1$ diterima, artinya ada pengaruh langsung antara Dana Pihak Ketiga terhadap laba bersih pada PT.Bank Negara Indonesia (Persero), Tbk.

\section{Pembahasan}

Berdasarkan hasil analisis dan interpretasi data membuktikan bahwa Dana Pihak Ketiga (DPK) berpengaruh positif dan signifikan terhadap laba bersih pada PT. Bank Negara Indonesia (Persero), Tbk periode 2010-2019. Hal ini berarti bahwa setiap peningkatan Dana Pihak Ketiga akan diikuti juga dengan peningkatan terhadap pendapatan bank, dimana ketika jumlah DPK banyak disalurkan ke dalam bentuk kredit, maka pendapatan dari kredit tersebut akan naik sekaligus memberikan implikais bahwa kemampuan bank dalam menghasilkan laba akan semakin meningkat. Hasil penelitian ini konsisten dengan penelitian Permatasari (2017) yang melakukan penelitian terhadap bank di Indonesia juga menghasilkan temuan bahwa Dana Pihak Ketiga berpengaruh positif dan signifikan terhadap laba bersih. Hal ini mengindikasikan bahwa semakin banyak simpanan nasabah yang dihimpun bank maka akan meningkatkan kegiatan usaha bank untuk memperoleh profitabilitasnya. Sehingga bank diharapkan mampu mendorong nasabah untuk meningkatkan simpanannya agar dapat memaksimalkan profitabilitasnya dengan menjaga spread antara bunga simpanan dan bunga kredit serta menjaga agar dana tidak idle Oleh karena itu bank dituntut kreatif untuk mengembangkan produk - produk yang menarik dan sesuai dengan kebutuhan nasabah guna menambah dana pihak ketiga yang dihimpun oleh bank.

Dana-dana yang dihimpun dari masyarakat (Dana Pihak Ketiga) ternyata merupakan sumber dana terbesar yang paling diandalkan oleh bank (bisa mencapai $80 \%$ - 90\% dari seluruh dana yang dikelola oleh bank). Menurut Muljono, (2013) Dana Pihak Ketiga (DPK) adalah dana yang dihimpun dari masyarakat akan digunakan untuk pendanaan sektor riil melalui penyaluran kredit. Peningkatan Dana Pihak Ketiga (DPK) yang terdiri dari Giro, Tabungan serta Deposito tersebut disebabkan karena adanya kepercayaan masyarakat terhadap PT. Bank Negara Indonesia (Persero), Tbk untuk menanamkan kembali uang dalam bentuk tabungan, giro dan deposito. Karena Dana pihak ketiga atau dana yang dihimpun dari masyarakat merupakan sumber dana terbesar yang paling diandalkan oleh bank.

Penelitian yang dilakukan oleh Luh Puspawati, Wayan Cipta, Ni Nyoman Yulianthini (2016) juga menunjukan bahwa ada pengaruh yang positif dan signifikan dari Dana Pihak Ketiga dan Jumlah Penyaluran Kredit terhadap Laba. Selanjutnya hasil penelitian terdahulu yang dilakukan oleh Fauziah Durotul Masruroh (2018) yang meneliti tentang pengaruh Dana Pihak Ketiga (DPK) dan Jumlah Pembiayaan terhadap Laba BNI Syariah yang menyimpulkan bahwa Dana Pihak Ketiga berpengaruh terhadap Laba BNI Syariah. Dalam penelitian ini, ditemukan secara parsial bahwa DPK berpengaruh 
signifikan terhadap laba, maka hipotesis H1 diterima. Hasil penelitian ini mengindikasikan bahwa peningkatan DPK selama periode penelitian mempengaruhi laba secara signifikan. Dengan demikian, maka semakin tinggi DPK yang berhasil dihimpun oleh perbankan, akan mampu mendorong peningkatan jumlah laba yang diperoleh.Hal itu terjadi karena laba dari penyaluran DPK akan berpotensi meningkat

Penyaluran dana menjadi prioritas utama bank dalam pengalokasian dananya. Hal ini dikarenakan sumber dana bank berasal dari masyarakat sehingga bank harus menyalurkan kembali DPK yang berhasil dihimpun kepada masyarakat dalam bentuk pembiayaan. Hal ini sejalan dengan fungsi bank sebagai perantara keuangan (financial intermediary). Disamping itu penyaluran dana merupakan aktivitas yang paling utama bagi Bank selaku business entity dalam menghasilkan keuntungan. Pengalaman dan kemampuan yang dimiliki juga turut mendukung keberanian Bank dalam menyalurkan dana.

\section{SIMPULAN}

\section{Kesimpulan}

Berdasarkan hasil analisis dan pembahasan, maka dapat disimpulkan bahwa DPK (Dana Pihak Ketiga) periode tahun 2010-2019 berpengaruh signifikan terhadap laba bersih. Hal ini dapat dilihat pada hasil uji t variabel X (DPK) diperoleh t hitung lebih besar dari pada t-tabel $(9,929>2,306)$. Dengan demikian terbukti bahwa Dana Pihak Ketiga berpengaruh positif dan ignifikan terhadap laba bersih pada PT. Bank Negara Indonesia (Persero), Tbk. Hal ini mengindikasikan bahwa semakin banyak simpanan nasabah yang dihimpun oleh PT. Bank Negara Indonesia (Persero), Tbk maka dapat meningkatkan kegiatan usaha bank untuk memperoleh laba bersih yang optimal.

\section{Saran}

Diharapkan bagi industri perbankan yang ada di Indonesia khususnya PT. Bank Negara Indonesia (Persero), Tbk agar dapat meningkatkan simpanan Dana Pihak Ketiga, karena semakin tinggi Dana Pihak Ketiga yang dihimpun oleh bank merupakan sinyal positif terhadap profitabilitas (laba bersih) bank. Selain itu, manajemen bank dapat mengambil tindakan korektif apabila kinerja keuangan bank yang dipimpin mengalami penurunan.

Bagi penelitian selanjutnya disarankan untuk memperbanyak sampel penelitian. Selain itu, peneliti selanjutnya dapat mengembangkan variabel-variabel lain yang relevan selain variabel Dana Pihak Ketiga (DPK) sebagai variabel bebas seperti BOPO, NPL dan suku bunga dengan mempertahankan laba bersih perusahaan sebagai variabel dependen.

\section{DAFTAR PUSTAKA}

Andriani, R., \& Nugraha. 2018. Analisis Cost-Volume-Profit Kaitannya dengan Perencanaan Laba,. Jurnal Manajemen Keuangan. Ubhara Jaya .No. 54 - 66

Arfan Ikhsan, 2018. Analisa Laporan Keuangan, Jilid ke dua. Medan : Madenatera

Arfan Ikhsan Lubis., 2013., Akuntansi Keperilakuan. Edisi.2, Jakarta. Salemba Empat

Budi Rajarjo, 2010. Laporan Keuangan Perusahaan. Edisi kedua, Penerbit Gadjah Mada University Press. Yogyakarta.

Erna Sudarmawanti, Joko Pramono. 2017. Pengaruh CAR, NPL, BOPO, NIM dan LDR Terhadap ROA Pada Bank Perkreditan Rakyat di Salatiga yang Terdaftar di Otoritas Jasa Keuangan 2011-2015. Vol. 10. No 19.

Fauziah Durotul Masruroh \& Rokhmat Subagiyo. 2019. Pengaruh Dana Pihak Ketiga Dan Jumlah Pembiayaan Terhadap Laba Bank Syariah Mandiri. Jurnal Ilmu Ekonomi dan Keislaman Volume 7 Nomor 1.

Ghozali, Imam. 2016. Aplikasi Analisis Multivariate dengan Program IBM SPSS 23 Update PLS Regresi. Semarang: Universitas Diponegoro 
Hans Kartikahudi, dkk. 2012. Akuntansi Keuangan berdasarkan SAK berbasis IFRS. Jakarta: Salemba Empat.

Harahap, 2011. Analisa Kritis atas Laporan Keuangan, Edisi ke-5, Jakarta: Rajawali Pers

Halim. Abdul. 2014, Akuntansi Sektor Publik Akuntansi Keuangan Daerah, Edisi Empat, Jakarta. Salemba Empat

Ismail. 2013. Akuntansi Bank Teori dan Aplikasinya dalam Rupiah, Jakarta : Prenadamedia Group.

Kasmir. 2015. Bank Dan Lembaga Keuangan Lainnya, Jakarta. Rajawali Pers.

Luh. Puspawati, Wayan Cipta, Ni Nyoman Yulianthini, 2016. Pengaruh Dana Pihak Ketiga Dan Jumlah Penyaluran Kredit Terhadap Laba. Journal Bisma Universitas Pendidikan Ganesha Jurusan Manajemen Volume 4.

Mulyono, Teguh. P, 2016. Manajemen Perkreditan Bagi Perbankan Komersil, Yogyakarta. BPFE. Otoritas Jasa Keuangan. 2017. Surat Edaran Otoritas Jasa Keuangan. Nomor 39/SEOJK.03/2017. Peraturan Bank Indonesia Nomor 15/15/PBI/2013 Tentang Giro Wajib Minimum Bank Umum

Rivai, Veithzal dan Rifki Ismail. 2013. Islamic Risk Management For Islamic Bank. Jakarta. PT Gramedia Pustaka Utama.

Sugiyono. 2017. Metode Penelitian Bisnis. Alfabeta: Bandung

Stice, Skousen dkk. 2011. Akuntansi Keuangan Menengah I (Terjemahan). Jakarta. Salemba Empat.

Wiwin Winarsih, Pembiayaan Dana Pihak Ketiga Pada Pertumbuhan Laba Bersih Bank BNI Syariah. Jurnal Ekonomi Syariah dan Filantropi Islam. Vol. 1, No. 2

Wiagustini, Ni Luh Putu. 2018. Dasar-Dasar Manajemen Keuangan. Pertama. Udayana Universitas Press.

Kasmir, 2014. Bank dan Lembaga Keuangan Lainnya. Jakarta. Raja Grafindo Persada. IBI, 2017. Mengelola Kualitas Layanan Perbankan. Jakarta. Gramedia Pustaka Utama https://www. bni.co.id

IBI, 2017. Mengelola Kualitas Layanan Perbankan. Jakarta.Gramedia Pustaka Utama. 